\title{
Intercultural Education in Mexico - Low Income and Poverty in Universidad Intercultural Maya de Quintana Roo’s (UIMQROO) Students
}

\author{
Miguel Barrera, Valeria Cuevas, Oscar Reyes, and Yolima Olvera
}

\begin{abstract}
The intercultural university, as an innovative model in Latin America, has a major role in societies where the indigenous population is established; however, this population is typically limited in economic resources, which prevents young people to have full access to higher education. This causes that two major purposes of the intercultural model university do not exist: the hodgepodge of local knowledge with scientific one-work; and let young people to have access to the labor market to improve their income and their families. In this sense, this paper intends to outline through a study case to measure, using a World Bank indicator, the vulnerable economic situation that UIMQROO' students have, and how does that means a challenge for the intercultural university model in Mexico.
\end{abstract}

Index Terms-Poverty, intercultural model, Quintana Roo, income.

\section{INTRODUCTION}

The Intercultural college model implemented in higher education in Mexico by the Secretary of Public Education takes into account the inclusion of indigenous young adults in the academic and work life in the country (Map1). As a matter of fact The intercultural college model, according to the Public Education Ministry in Mexico "is mainly guided by a series of philosophical-evident principles proposed to address change the different dimensions of diversity in social relations, particularly in Mexican society which have been affected by the historical conditions that determined structural inequality, polarizing interests and sharply dividing the different sectors within it." [1], so, the objective population of this policy is the indigenous population specifically [2].

It must be remembered that intercultural universities are presented and conceived as a link in the chain of preschools, elementary and secondary level "with intercultural and bilingual approach", created in the "indigenous" multilingual regions and the country, which provide culturally relevant to students as defined and differentiated in various ethnic, linguistic or cultural terms education [3].

Other authors [1]-[3] suggest that intercultural college model aims to reverse the education process that led to eliminate the differences of cultures and drove him to safeguard the knowledge and values that have not sunk in isolation, they would have enhanced their chances of

Manuscript received July 10, 2015; revised January 18, 2016.

The authors are with Universidad Intercultural Maya de Quintana Roo, Mexico (e-mail: valeria.cuevas@uimqroo.edu.mx, Yolima.olvera@uimqroo.com) development. The main purpose of this approach is to exploit the differences in the process of complementation of knowledge built and shared with other subjects and other dimensions of development (community-region entity, nation, world) [1].

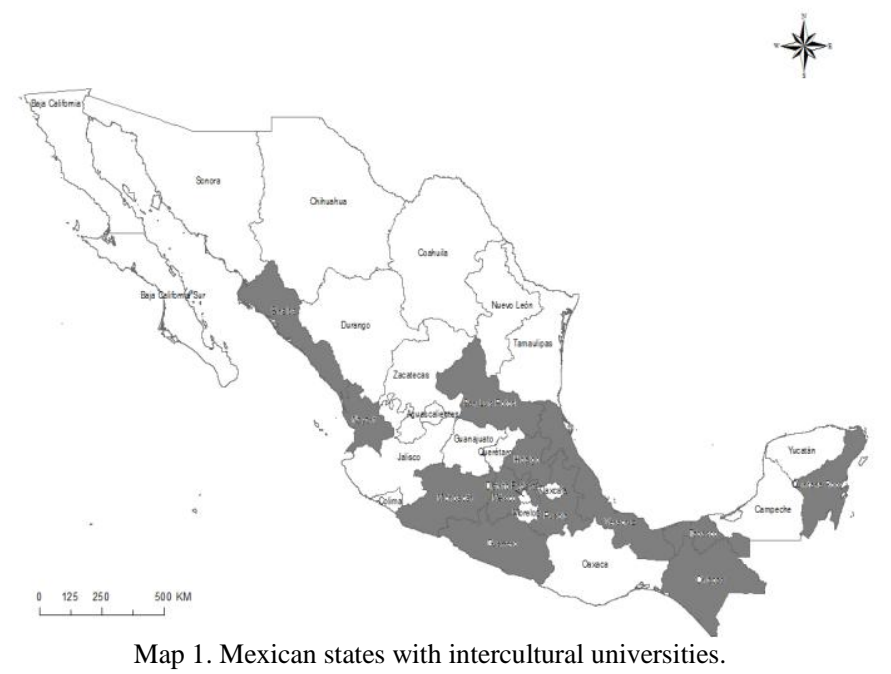

The soul of the intercultural college model is precisely the conjunction of the positivist scientific knowledge and local wisdom of indigenous peoples; its purpose is to explore modalities of relevant educational services for young people who aspire to pursue higher education level, both of indigenous origin and other social sectors, primarily interested in promoting the development of indigenous peoples and communities and to apply the knowledge built different contexts [1], [2]; and the mission of the Intercultural University is to promote the training of professionals committed to the economic, social and cultural development, particularly the indigenous peoples of the country and the world around; revalue the knowledge of indigenous peoples and foster a process of synthesis with the progress of scientific knowledge; promote the dissemination of the values of communities and create opportunities to promote the revitalization, development and consolidation of native languages and cultures to stimulate an appropriate notice of university tasks with the surrounding communities [1]-[3]. Thus, the difference should be seen as a quality that involves understanding and mutual respect among different cultures; and a list of sharing knowledge and values equal, thus offering a contribution to the development of knowledge, philosophy and worldview and the relationships therein in different circumstances are established between different actors [1], [2].

The new educational institutions designed from the 
beginning of this intercultural approach will contribute to the rescue and dissemination of diverse cultural expressions and work to establish close links of direct communication between the ancient cultures with the modern world. This will help the indigenous peoples to design-in a relationship equitable- collaborative links and contributions to scientific knowledge through critical and creative vision, facilitates the generation of development proposals adapted to their culture, traditions, expectations and interests and they are kept in dynamic contact with other cultures. Nevertheless, the indigenous zones are also places where a high level of poverty exists and scarcity related to the incomes and this obviously represents a big challenge for the Intercultural College model. Being facing this panorama, the Intercultural Mayan University of Quintana Roo has implemented the Intercultural Health College Program "which is a project aimed at knowledge, maintenance, and improvements in the health aspect inside the college community. As part of the activities, the program is carrying out a diagnostic which allows to publish which the health situation is with the students and also all the social factors that influence on the health situation. Due to this the first objective of the current project is to eradicate the aforementioned problematic" [4] and its main purpose was to diagnose the socioeconomic status, sexual, mental and physical health in our students so as to plan strategies that could allow a big improvement in the Intercultural model.

In the literature review, there is evidence of prior studies where there is analysis about different factors that cause dropping out of the school. For instance, reference [5] analyzes in a very specific manner the role of the socioeconomic factors such as incomes and outcomes are related to the dropping out of school in high school students in the state of Yucatan [6] shows a very interesting analysis about the social factors focusing on the merely family ones because these factors rebound the student's economy and this provokes leaving the primary school in poor urban areas in Chile; Other authors such as [7] point out that the economic factor is important; however, it is not the factor which influences more related to the dropping out the school.

While [8] make a strong review based on the causes and consequences of early-school leaving which is due to the lack of economic resources since they propitiate the poverty trap: "dropping out the school creates high private and social costs". The first ones are not that easy to estimate, but some of them are mentioned because they dispose a less competent labor force and more difficult to designate when people have not reached certain minimum levels of education to take advantages from training programs which have been offered by the state or enterprises and which the most extreme manifestation is illiteracy.

The low labor productivity and its least effect on the growth of the economies are also considered as a social cost from a low level of education which produces the early-school leaving considering the first months of the school year. Additionally, dropping out of school represents a social cost which is one of the higher costs where it is necessary to incur so as to finance social and transfer programs to different sectors which do not generate their own resources. As well, it is also mentioned that the early-school leaving costs are also part of the intergenerational reproduction of social inequalities, poverty, and its negative impact in the social integration. These elements make the democracy strengthening and deepening difficult." Thus, after making an exhaustive literature review, this task is very relevant because it focuses on studied units of analysis such as poverty in college students in an intercultural model.

\section{Methodology}

A simple sampling with a margin of $10 \%$ error, at the $90 \%$ confidence level, 609 students as a population size and a $50 \%$ of answer arrangement was used. The reason to use a $90 \%$ confidence level is due to the PROSIU which is a pilot program in the university and this is the motivation to bear the possible maximum error that has been suggested by authors such as [9]. PROSIU, which it is a program implemented by UIMQROO in order to diagnose psychological and physical health and economic situation of their students. The first version was implemented in 2012 and emerged as part of the needs identified by the Community Health Major to improve the educational quality of the UIMQROO [10]. The survey has 3 categorical areas: mental health, which includes issues such as addictions, stress management, situations of sexual harassment and bullying; physical health, which includes topics such as food, feeding frequency, power quality, healthy practice sport, pregnancy prevention and sexually transmitted diseases; and economic situation, in which the variable income in much the same way as does the INEGI national survey of income and expenditure in the way homes are built Mexico.

From this diagnostic, the economic variables were isolated to get information about the students' income. To do so, and as a support from other studies about the incomes in the Mayan zone from Quintana Roo, the Total Income formula (TI) was used which it was suggested by [11], [12], where the total income (TI) is the sum of the Monetary Incomes (MI) and Non-Monetary Incomes (NMI):

$$
T I=M I+N M I
$$

The sampling formula that was used:

$$
n=\frac{N * z^{2} * p * q}{e^{2}(N-1)+\left(z^{2} * p * q\right)}=61 \text { surveys. }
$$

Subsequently, obtaining the variable TI, the students' incomes were located against all the poverty lines which are suggested by CONEVAL in Mexico. The importance of using the poverty lines has been one of the most worn methods to measure the poverty throughout the lack of incomes since 1880 and this happened in a Royal Statistical Society conference where a proposal was made about dividing the population in lines having in mind the salary; that is to say the families who get a certain amount of income and a certain level of employment will be "above the poverty line" [13]. The academic use of the poverty lines has been such a success that even international institutions such as World Bank has been using them in their [14]-[18] reports to define how extreme poor population can survive the day with less than \$1.25 and \$2.50 American dollars which expresses the Purchasing Power Parity (PPP). Thus, it will be analyzed 
if the students have the daily incomes below \$2.50 American dollars as it is proposed by the World Bank.

\section{RESULTS}

As it is observed in the Fig. 1, the $17 \%$ of the sampling shows incomes below \$2.50 American dollars per day and this is considered as extreme poverty and in this way the percentage is not that high and it comes out that one-fifth of the sampling shows really unfavorable economic conditions to face the process of college education and they are in total disadvantage not only educational, but also nutritional and the environment respecting to the college partners.

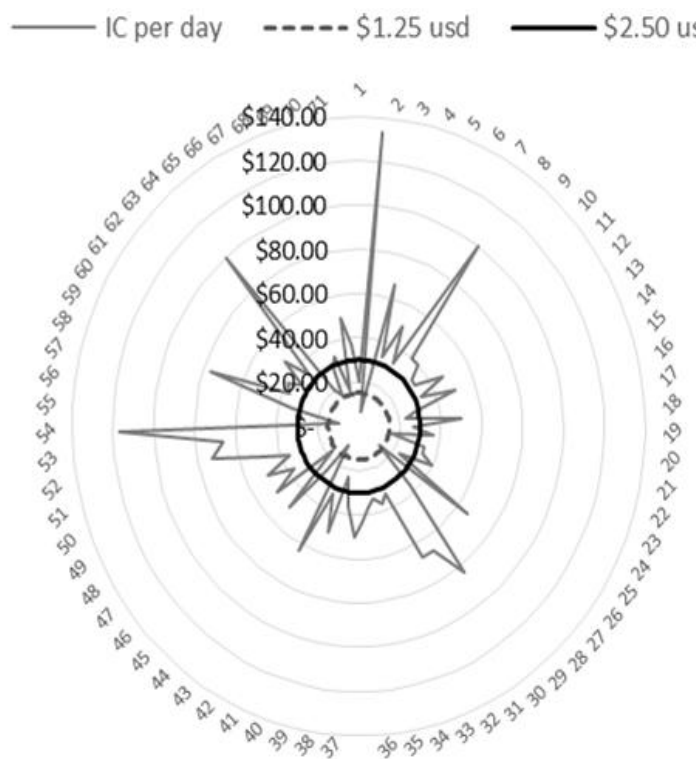

Fig. 1. Daily income per capita in UIMQROO students versus World Bank's extreme poverty lines (2005 average exchange rate).

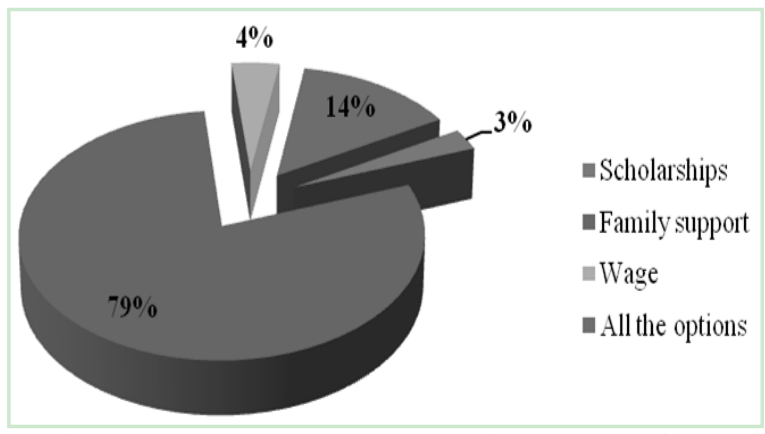

Fig. 2. Where do UIMQROO students'incomes come from?

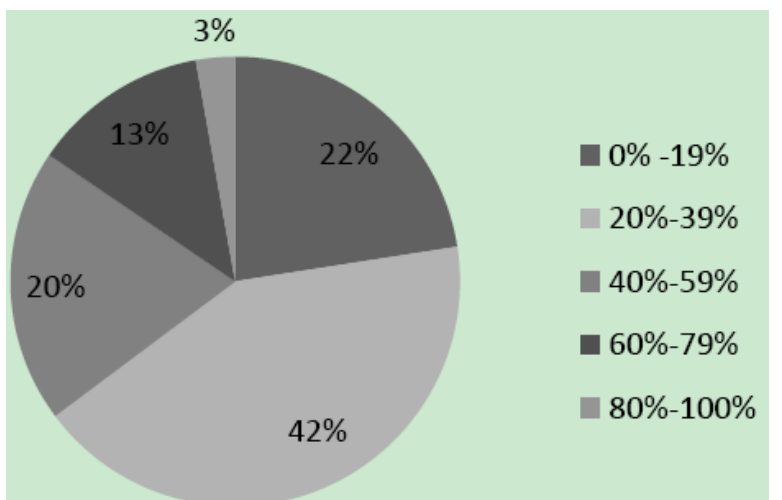

Fig. 3. How much of their income do UIMQROO' students spend in food.

Now in Fig. 2, it can be observed the origins of all available monetary resources for all the students. In the first place, the family support is necessary, as well as scholarships and salaries and finally combinations of three options. In Fig. 3 3it can be observed how much of their income do UIMQROO' students spend in food, which is a basic need. With this simple change, it can be noticeable that the students' percentage which are in an extreme poverty situation up to $57.74 \%$; it means that is more than half of the sampling.

\section{CONCLUSIONS}

The evidence that there are students who are located in the extreme poverty line according to World Bank and this propitiates that the number of students in the Intercultural Universities in Quintana Roo and Mexico is committed. It is important to bring out that the lack of monetary resources as [8] have established is not only this problem to be solved due to the fact that the shortage of money affects in students who have bad food habits and this provokes difficulties during the learning process and they also feel discrimination for not having money.

In Mexico and in a very special situation which the Mayan zone is, there are the conditioned cash transfers [10], [11] and they alleviate a little bit the problems; however, the origins of poverty are not solved and this case of study reflects the situation perfectly well.

If the Intercultural Universities were designed based on a long period, they should need to start solving the problems that are facing, in special the ones that are talked about in this study, which condition the permanency of indigenous young students for completing and finishing all their credits in the university not only from the Quintana Roo state[19]-[22], but also from Mexico and Latin American. These kind of studies need to be considered by the people who are in charge of taking public decisions for a good design and complementation of the same choices.

It is extremely necessary for decision makers in Mexico think that intercultural model is subject not only to the interaction of traditional knowledge with conventional construction processes science, but also greatly influences the economic situation of students and their families . In studies on poverty in the indigenous zone of Quintana Roo had already shown that there is very high and worrying levels of poverty [9], [10], so it was expected that a good portion of tuition UIMQROO is within the World Bank parameters considered extreme poverty. This certainly becomes fragile intercultural model not on their mission and vision, but its viability as, as is done at present through student numbers you enter and graduate.

Thus, both the state government and federal government should implement programs that directly affect the income of indigenous university students and in general throughout the country, so that their stay at the university is not compromised for reasons of monetary insolvency.

\section{REFERENCES}

[1] Secretaría de EducaciónPública (w/d). Enfoque intercultural en la educaciónsuperior. [Online]. Available: http://eib.sep.gob.mx/cgeib/desarrollo-de-modelos/universidad-interc ultural/

[2] L. Casillas and L. Santini, Universidad Intercultural: Modelo Educativo, Mexico, 2006. 
[3] L. S. M.Cortés and G. Dietz, Relaciones. Estudios de Historia y Sociedad, vol. 36, no. 141, pp. 13-45, 2015.

[4] C. Montejo, Diagnóstico de Salud Integral Universitaria. Resultados Preliminares, Mexico, 2015

[5] J. Castro, "Factores socioeconómicos que influyen en la deserción escolar de los estudiantes de un sistema de preparatorias, México," Congreso Nacional de Investigación Educativa, pp. 1-9. 2011.

[6] O. Espinoza, D. Castillo, L. González, and J. Loyola, "Factores familiares asociados a la deserción escolar en Chile," Revista de Ciencias Sociales, pp. 136-150, 2012.

[7] G. J. Paramo and C. A. C. Maya, "Deserción estudiantil universitaria," Conceptualización. Revista Universidad EAFIT, vol. 35, no. 114, pp. 65-78, 2012.

[8] E. Espíndola and A. León. (2002). La deserción escolar en América Latina: un tema prioritario para la agenda regional. Revista Iberoamericana de Educación. [Online]. 30(3). Available: http://www.rieoei.org/rie30a02.htm

[9] L. Kish, Muestreo de Encuestas, México:Trillas, 1982.

[10] C. Montejo, Diagnóstico del PROSIU, México, Universidad Intercultural Maya de Quintana Roo, 2014.

[11] M. Barrera, and O. Reyes, "Pobreza y transferencias monetarias en comunidades mayas de México: José María Morelos y Sabán, Quintana Roo, 2011," Equilibrio Económico Revista de Economía Política y Sociedad, vol. 9, no. 2, pp. 201-228, 2013.

[12] M. Barrera, O. Reyes, and Y. Olvera, "Conditionated monetary transferences (CMT) in Mexico's mayan villages income structure: José María Morelos and Saban, Quintana Roo," Entreciencias, Diálogos de la Sociedad del Conocimiento, pp. 57-69, 2015.

[13] A. Gillie, "The origin of the poverty line," Economic History Review, pp. 715-730, 1996.

[14] World Bank, World Development Report 2000/2001: Attacking Poverty, New York: Oxford University Press, 2000.

[15] World Bank, World Development Report 2006: Equity and Development, New York: Oxford University Press, 2005.
[16] World Bank, Global Purchasing Power Parities and Real Expenditures, 2005 International Comparison Program, Washington, DC, 2008.

[17] World Bank, World Development Indicators Database, Washington, DC, 2008b.

[18] World Bank, Latin America and the Caribbean Poverty and Labor Brief, June 2013.

[19] M. Aguilar, "Universidades interculturales, adjetivo o sustantivo," Congreso Nacional de Investigación Educativa, COMIE, México, 2011.

[20] L. Mateos and G. Dietz,"Universidades Interculturales en México," Multiculturalismo y Educación: Estado del Conocimiento 2002-2011, México, ANUIES-COMIE, 2013.

[21] D. Lehmann, "Convergencias y divergencias en la educación superior intercultural en México," Revista Mexicana de Ciencias Políticas y Sociales, vol. 60, no. 223, pp. 133-170, 2015

[22] F. G. Ortiz, "La construcción de un modelo de educación superior intercultural," La Universidad Intercultural, vol. 11, no. 3, 2015.

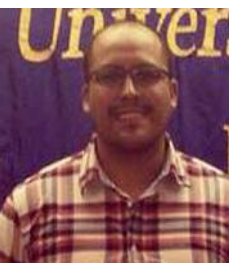

Miguel Barrera was born in Mexico city, on Dec. $31^{\text {st }}, 1985$. He got the B.A. in financial economics (2004-2008 Mexico city, Mexico) by Escuela Bancaria y Comercial; the M.Sc. in regional development (2008-2010 Tijuana, Mexico) by El Colegio de la Frontera Norte; and the Ph.D. (candidate 2013-2016 Chetumal, Mexico) in geography by Universidad de Quintana Roo.

$\mathrm{He}$ is professor at Universidad Intercultural Maya de Quintana Roo in the Centro Intercultural de Proyectos y Negocios (2011-nowadays). He was professor (2010-2011) at Universidad del Mar campus Huatulco in the Tourism Institute, and was one member of the III Class on Legislative Process by Partners of the Americas in City University of New York at Ernesto Malave Leadership Academy. 